\title{
'Bubbling reefs' in the Kattegat: submarine landscapes of carbonate-cemented rocks support a diverse ecosystem at methane seeps
}

\author{
P. Jensen ${ }^{1}$, I. Aagaard ${ }^{1}$, R. A. Burke $\mathrm{Jr}^{2, *}$, P. R. Dando ${ }^{3}$, N. O. Jørgensen ${ }^{4}$, A. Kuijpers ${ }^{5}$, \\ T. Laier ${ }^{5}$, S. C. M. O'Hara ${ }^{3,6}$, R. Schmaljohann ${ }^{7}$ \\ ${ }^{1}$ Marine Biological Laboratory, University of Copenhagen, Strandpromenaden 5, DK-3000 Helsinger, Denmark \\ ${ }^{2}$ Geochemical and Environmental Research Group, Texas A\&M University, College Station, Texas 77845, USA \\ ${ }^{3}$ Marine Biological Association of the U.K., Citadel Hill, Plymouth PL1 2PB, United Kingdom \\ ${ }^{4}$ Geological Institute, University of Copenhagen, Øster Voldgade 10, DK-1350 Copenhagen, Denmark \\ ${ }^{5}$ Geological Survey of Denmark, Thoravej 8, DK-2400 Copenhagen, Denmark \\ ${ }^{6}$ Plymouth Marine Laboratory, Prospect Place, Plymouth PL1 3DH, United Kingdom \\ ${ }^{7}$ Institut für Meereskunde an der Universität Kiel, Düsternbrooker Weg 20, W-2300 Kiel, Germany
}

\begin{abstract}
Methane seeps in shallow waters in the northern Kattegat of the Danish coast form spectacular submarine landscapes - the 'bubbling reefs' - due to carbonate-cemented sandstone structures which are colonized by brightly coloured animals and plants. These structures may be $100 \mathrm{~m}^{2}$ in area and consist of pavements, complex formations of overlying slab-type layers, and pillars up to $4 \mathrm{~m}$ high. The carbonate cement (high-magnesium calcite, dolomite or aragonite) is ${ }^{13} \mathrm{C}$-depleted, indicating that it originated as a result of microbial methane oxidation. It is believed that the cementation occurred in the subsurface and that the rocks were exposed by subsequent erosion of the surrounding unconsolidated sediment. The formations are interspersed with gas vents that intermittently release gas, primarily methane, at up to $25 \mathrm{l} \mathrm{h}^{-1}$ The methane most likely originated from the microbial decomposition of plant material deposited during the Eemian and early Weichselian periods, i.e. 100000 to 125000 years B.P. Aerobic methane oxidation in the sediment was restricted to the upper $4 \mathrm{~cm}$ in muddy sand and to the upper $13 \mathrm{~cm}$ in coarse sand. Maximum aerobic methane oxidation rates ranged from 4.8 to $45.6 \mu \mathrm{mol} \mathrm{dm} \mathrm{dm}^{-3} \mathrm{~d}^{-1}$. The rock surfaces and epifauna around the seeps were also sites of methane-oxidizing activity. Integrated sulphate reduction rates for the upper $10 \mathrm{~cm}$ of muddy sand gave 4.2 to $26.6 \mathrm{mmol} \mathrm{SO}_{4}{ }^{2-} \mathrm{m}^{-2} \mathrm{~d}^{-1}$ These rates are higher than those previously reported from similar water depths in the Kattegat but did not relate to the sediment methane content. Since gas venting occurs over several $\mathrm{km}^{2}$ of the sea floor in the Kattegat it is likely to make a significant local contribution to the cycling of elements in the sediment and the water column. The rocks support a diverse ecosystem ranging from bacteria to macroalgae and anthozoans. Many animals live within the rocks in holes bored by sponges, polychaetes and bivalves. Stable carbon isotope composition $\left(\delta^{13} \mathrm{C}\right)$ of tissues of invertebrates from the rocks were in the range -17 to $-24 \%$, indicating that methane-derived carbon makes little direct contribution to their nutrition. Within the sediments surrounding the seeps there is a poor metazoan fauna, in terms of abundance, diversity and biomass. This may be a result of toxicity due to hydrogen sulphide input from the gas.
\end{abstract}

\section{INTRODUCTION}

Precipitation of carbonate cements and local lithification of marine sediments is frequently observed in association with gas migration through porous sedi-

\footnotetext{
- Present address: U.S. Environmental Protection Agency, Envi-
} ronmental Research Laboratory, Athens, Georgia 30613, USA ments. This has been shown, for example, by Ritger et al. (1987) from the Oregon Subduction zone at ca $2000 \mathrm{~m}$ water depth, by Hovland \& Judd (1988) from the North Sea at 74 to $245 \mathrm{~m}$ depth, by Roberts et al. (1988) from the Gulf of Mexico at ca $2000 \mathrm{~m}$ depth, and by $\mathrm{N}$. O. Jørgensen (1989) from the shallow waters in the Kattegat. These carbonates are remarkably ${ }^{13} \mathrm{C}$ depleted, with $\delta^{13} \mathrm{C}$ values generally in the range of 
-40 to $-55 \%$. Such depletion is characteristic of methane-derived carbonates which are formed as the result of microbial methane oxidation (Whiticar \& Faber 1986, Suess \& Whiticar 1989). Methane oxidation is believed to take place either in the anoxic environment in association with sulphate reduction or in oxic environments through the activity of aerobic methane-oxidizing bacteria.

The associated macrofauna on carbonate-cemented rocks has briefly been described from the Oregon Subduction zone (Kulm et al. 1986), the North Sea (Hovland \& Judd 1988) and the Gulf of Mexico (Roberts et al. 1988). Pore water chemistry and interstitial biota from these sites have so far only been studied at a pockmark in the North Sea (Dando et al. 1991).

Carbonate cementation has been known for some time in the northern Kattegat, Denmark, but was originally believed to be remains of old concrete structures. For decades local fishermen have found fragments in their nets. They called these fragments 'corals' due to the brightly-coloured animals (like sea ancmones) attached to the hard sandstonc; slabs without animals are called 'sponge cakes' due to their flattened appearance and the holes caused by animal borings. Here we show that such cemented sandstones originate from a submarine landscape, modified by methane seepage, containing up to $4 \mathrm{~m}$ high carbonate-cemented sandstone formations, the 'bubbling reefs', in shallow waters in the Kattegat. We also present results of subsequent laboratory analyses of associated abiotic and biotic parameters in the sediments and on the 'bubbling reefs'. Finally, we review the literature on gas and carbonate cement from the northern Kattegat.

Consideration is now being given by the Danish Ministry of the Environment to the establishment of a submarine National Park in the 'bubbling reef' area of the Hirsholm islands in the Kattegat.

\section{SITES AND METHODS}

Since 1989 we have studied several sites with carbonate-cemented sandstone formations and gas seepages in the northern Kattegat, Denmark, by means of video recordings and observations by SCUBA divers. Three sites at 10 to $12 \mathrm{~m}$ water depth were selected for more intensive research: 2 sites NW and SE of the Hirsholm islands off Frederikshavn $\left(57^{\circ} 30.64^{\prime} \mathrm{N}, 10^{\circ} 35.35^{\prime} \mathrm{E}\right.$ and $\left.57^{\circ} 28.35^{\prime} \mathrm{N}, 10^{\circ} 37.63^{\prime} \mathrm{E}\right)$ and 1 site north of the island Læsø $\left(57^{\circ} 25.06^{\prime} \mathrm{N}\right.$, $\left.11^{\circ} 01.25^{\prime} \mathrm{E}\right)$. Sediments at the 2 Hirsholm sites are muddy sand compared to well-sorted, medium grained sandy sediment at the Lcesø site.
All seciment and sandstone samples were collected by SCUBA divers. It was difficult to collect cores close to active gas seeps due to the presence of concretions of carbonate-cemented sediment. Dissection of $60 \mathrm{~mm}$ sediment cores taken over gas vents at an intertidal locality south of Frederikshavn has shown that the gas channels are seldom vertical, resulting in complex geochemical depth profiles (O'Hara, Dando \& Schuster unpubl. obs.). Samples for chemical, microbial and multicellular meiofauna analyses were collected with $30 \mathrm{~cm}$ long tubes, $5.5 \mathrm{~cm}$ in diameter and sealed with rubber stoppers at both ends. The cores were transported to the laboratory in a water bath at ambient bottom temperature. In the laboratory the cores were sliced horizontally at 1,2 or $4 \mathrm{~cm}$ intervals according to sediment depth, water content and the position of the redox potential discontinuity layer. Chemical and microbiological parameters were analyzed according to Dando et al. (1991) and meiofauna was treated as in Jensen (1983). Sediment samples for macrofauna analyses were collected with $25 \mathrm{~cm}$ long tubes, $12.5 \mathrm{~cm}$ in diameter and sealed with plates at both ends. In the laboratory the cores were sliced inte 5 horizental inter. vals: $0-2,2-5,5-10,10-15$ and $15-20 \mathrm{~cm}$ depth; each subcore was inspected for biogenic structures (tubes, burrows, etc.) prior to fixation in $4 \%$ formalin. The fauna was extracted and concentrated on a $500 \mu \mathrm{m}$ mesh size sieve. Estimation of faunal carbon content follows Brey et al. (1988). The $\delta^{13} \mathrm{C}$ of animal tissues was determined as outlined in Dando et al. (1991). Epibenthic fauna colonized with microbes were prepared for scanning electron microscopical (SEM) examinations by fixation with $2 \%$ glutaraldehyde followed by critical-point drying and sputter-coating. Samples for transmission electron microscopy (TEM) were fixed with $3 \%$ glutaraldehyde in phosphatebuffer, postfixed in $\mathrm{OsO}_{4}$, embedded in Spurr's resin, and sections were stained with uranyl acetate and lead citrate

\section{RESULTS AND DISCUSSION}

\section{The 'bubbling reefs' in the Kattegat: sandstone formations and seepages}

The sandstone structures are mainly composed of complex formations of overlying cemented slab-layers extending up to $2 \mathrm{~m}$ above the sediment surface. These formations sometimes contained crevices and occasional caves which could be gas-filled. Individual slabs can be more than $10 \mathrm{~m}^{2}$ Isolated pillars of up to $4 \mathrm{~m}$ height and diameter $1.5 \mathrm{~m}$ are also present (Fig. 1). More than 40 sites with sandstone formations have now been found in subtidal regions in the northern 


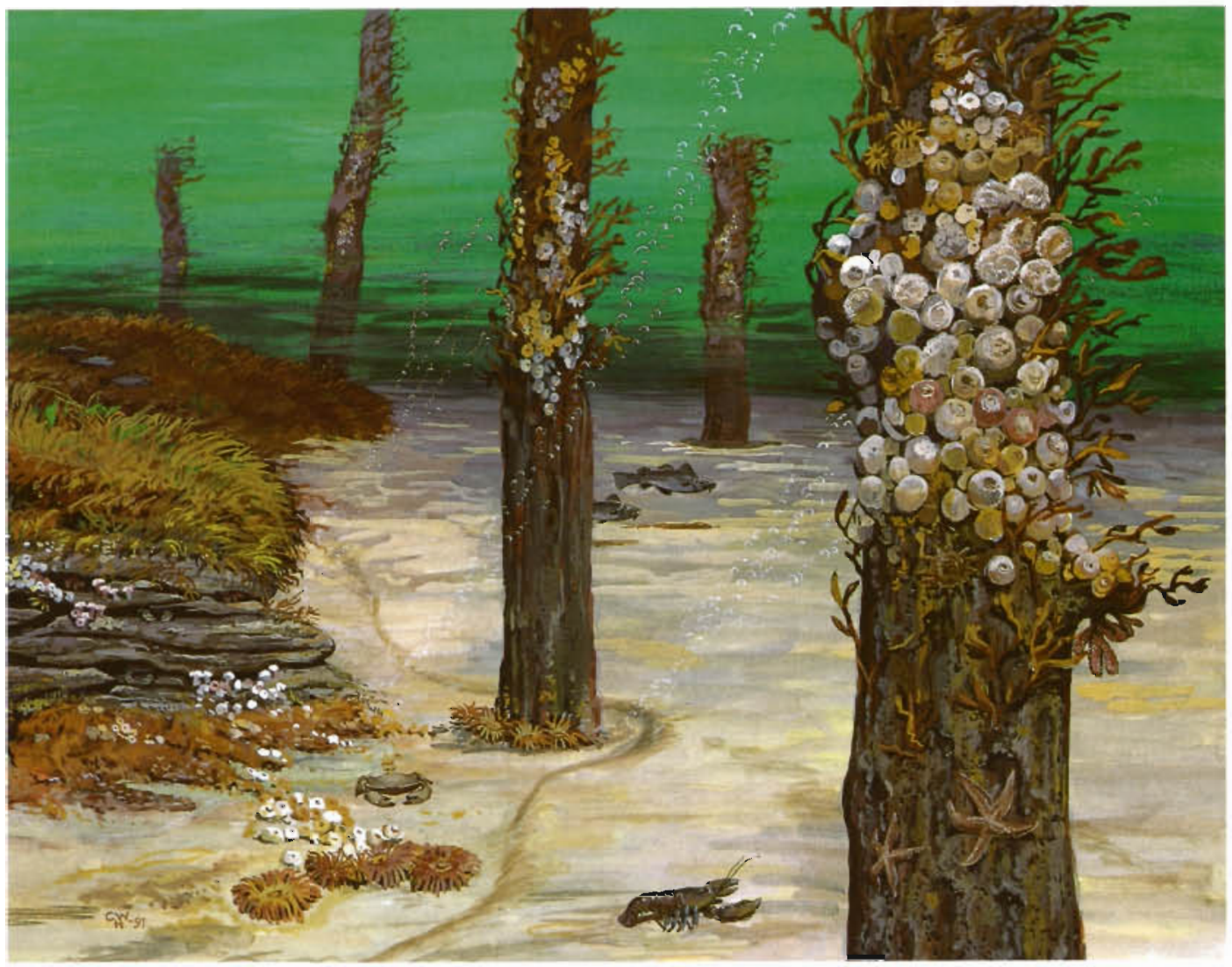

Fig. 1. Panorama of the submarine landscape 'the bubbling reefs' at 10 to $12 \mathrm{~m}$ water depth in the northern part of the Kattegat, Denmark. Artwork: Chr. Würgler Hansen.

Kattegat and also in the Skagerrak off Hirtshals (Fig 2). Recently, carbonate-cemented slabs and irregularly shaped lumps consisting of coarse shell debris and/or sand have been discovered in the intertidal zone south of Frederikshavn. N. O. Jørgensen (1989) suggested that the sandstone formations were formed in anaerobic layers of the sediment and were then exposed by subsequent erosion of the unconsolidated material (Fig. 3). This explains the absence of such formations in areas where sedimentation currently occurs. Several localities off the eastern coastline of Vendsyssel in northern Denmark and north of Læesø have an areal extension of more than $100 \mathrm{~m}^{2}$. The rocks lie in 0.5 to $1 \mathrm{~m}$ deep depressions which extend up to $3 \mathrm{~m}$ from the rocks indicating local erosion of fine material; the depressions may be partly filled with coarse shell debris.

Gas seepages are located in the vicinity of sandstone formations (Fig. 1). They occur as single holes or groups of holes, ca 1 to $5 \mathrm{~cm}$ in diameter, within $1 \mathrm{~m}^{2}$ of sea floor. The volume of released gas varies. Most seepages leak 1 to 51 gas $\mathrm{h}^{-1}$ but 2 seepages NW and

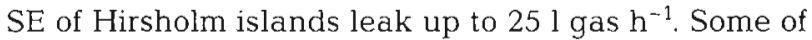
the released gas bubbles brush against the surfaces of rocks and biota, others are trapped in caves from which the gas leaks along the edge or through small channels in the rocks. Gas plumes in the water column may sometimes be detected on seismic recordings (Fig. 4A, B). In calm weather the sea above the seeps 'boils' (local fishermen's expression) due to the bursting of gas bubbles at the surface.

The area in which carbonate-cemented sandstone formations and gas seeps are found has a NW-SE extension that largely coincides with the general structural outline in the northern part of the Danish Sub-basin (EUGENO-S working group 1988). The distribution of the gas seeps is probably governed by the structural framework in the Fennoscandian border zone (Fig. 2). From seismic profiles (Fig. 4C) it appears that gas escapes to the surface from the gas-charged sediments at $10 \mathrm{~m}$ subbottom depth, forming distinct plumes in the sediments above.

We introduce the term 'bubbling reefs' for these bizarre submarine landscapes of rock formations formed of carbonate-cemented sediments and a gasbubbling sea floor. Methane-derived carbonate rocks on the sea floor have been described from many areas of the world (cf. Hovland 1990), although the gas seeps 


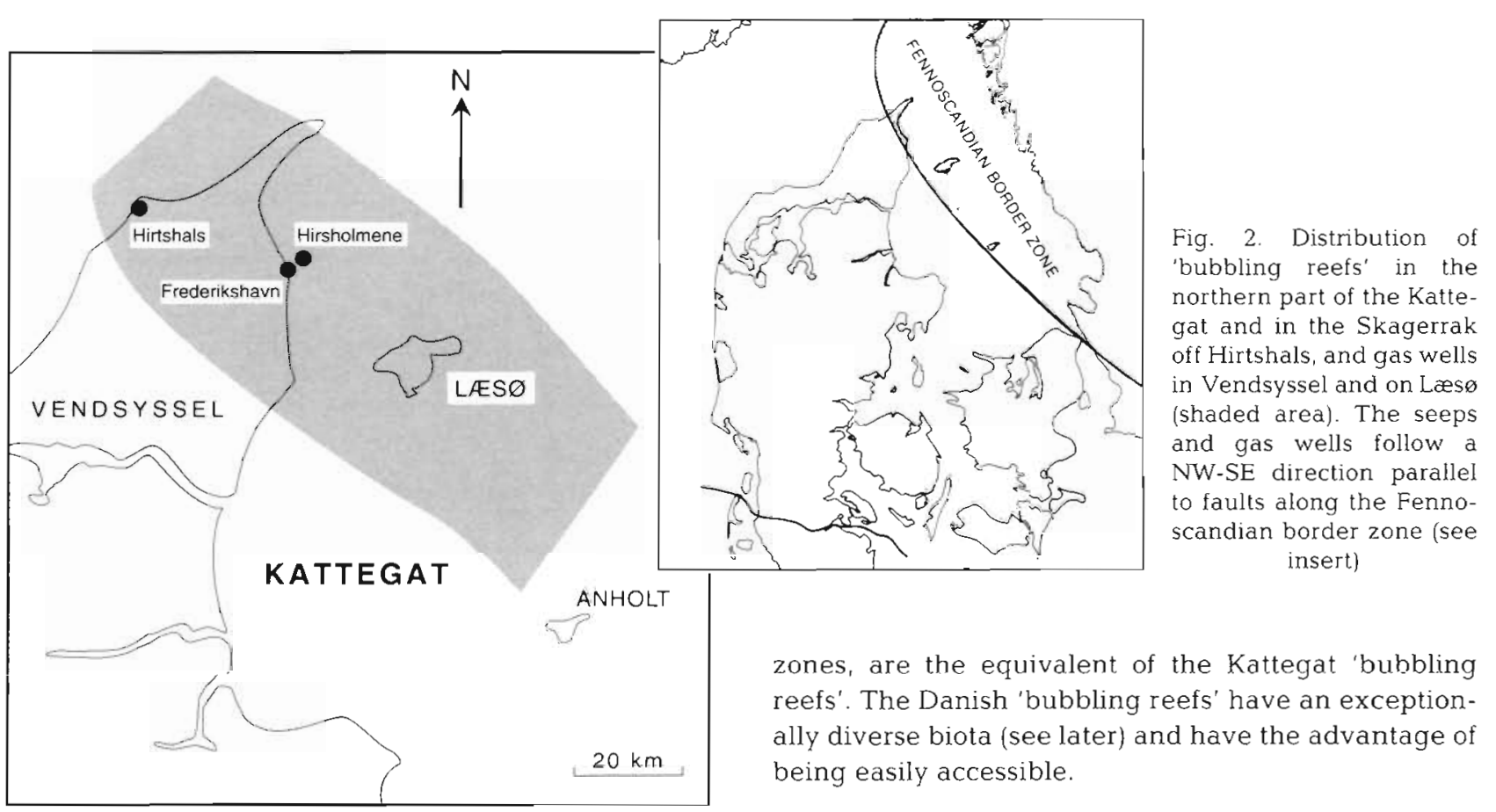

\section{Gas and carbonate cement}

are not always as obvious as in the Kattegat. There are site-to-site differences in the shape of the rock formations, the type of carbonate and the composition of the biological communities. Sandstone formations and seepages, such as those described from deeper waters in the North Sea, the Gulf of Mexico and subduction
Results of analyses of gas and carbonate cement were dealt with by N. O. Jørgensen $(1976,1989,1992)$ and N. O. Jørgensen et al. (1990). Based on TOC and Rock-Eval analyses of core samples from a $200 \mathrm{~m}$ deep well near the city of Frederikshavn Laier et al. (1992)
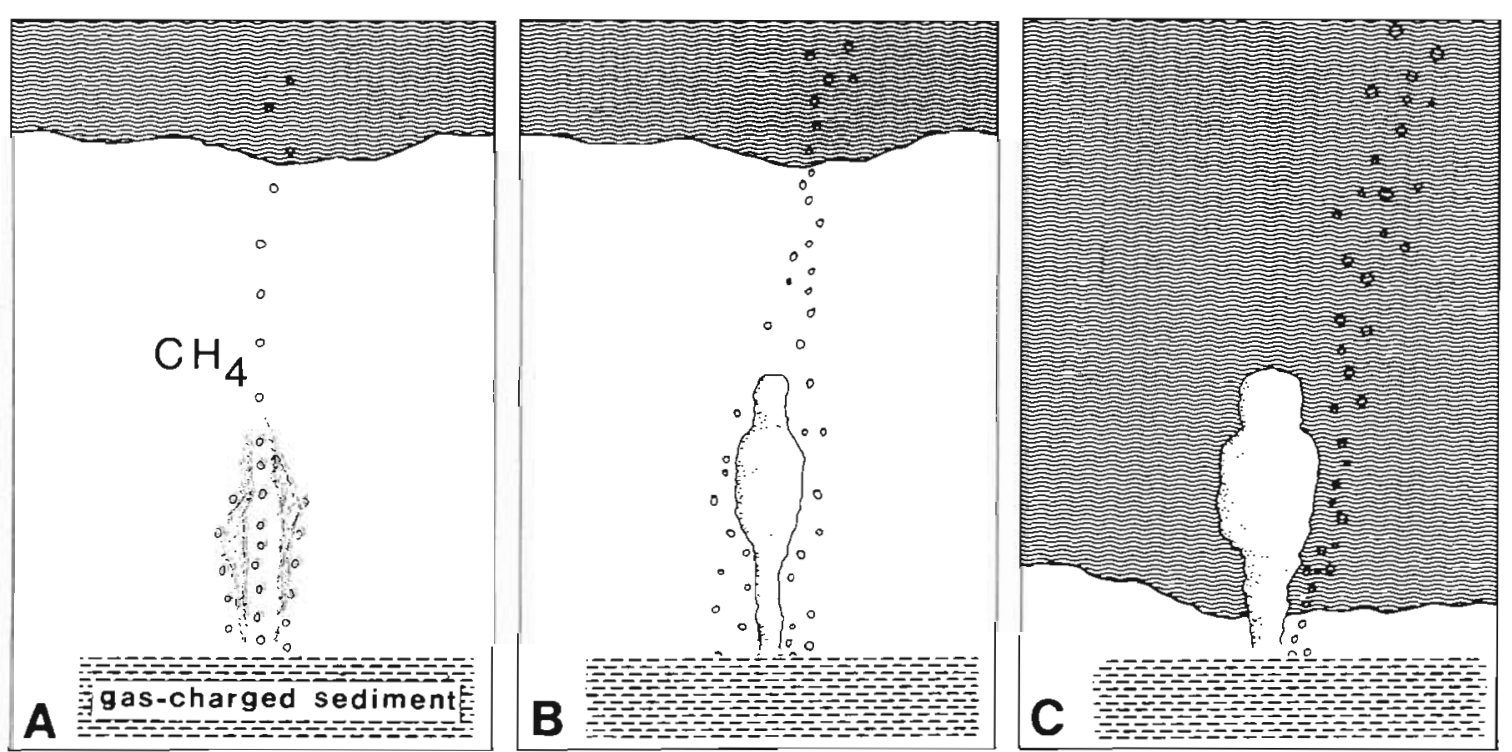

Fig. 3. Proposed formation of a $4 \mathrm{~m}$ high pillar at $10 \mathrm{~m}$ water depth in the Kattegat. (A) Methane-oxidation induces precipitation of carbonate which lithifies the sediment along gas channel. (B) Cementation of sediment fills channel and the pillar structure grows from outside. (C) Exposure of the carbonate-cemented sandstone pillar on sea floor as a result of erosion of unconsolidated sediment; methane seepage visible in the vicinity. Erosion may have been triggered by post-glacial isostatic uplift in the Kattegat area. Artwork: Chr. Würgler Hansen 

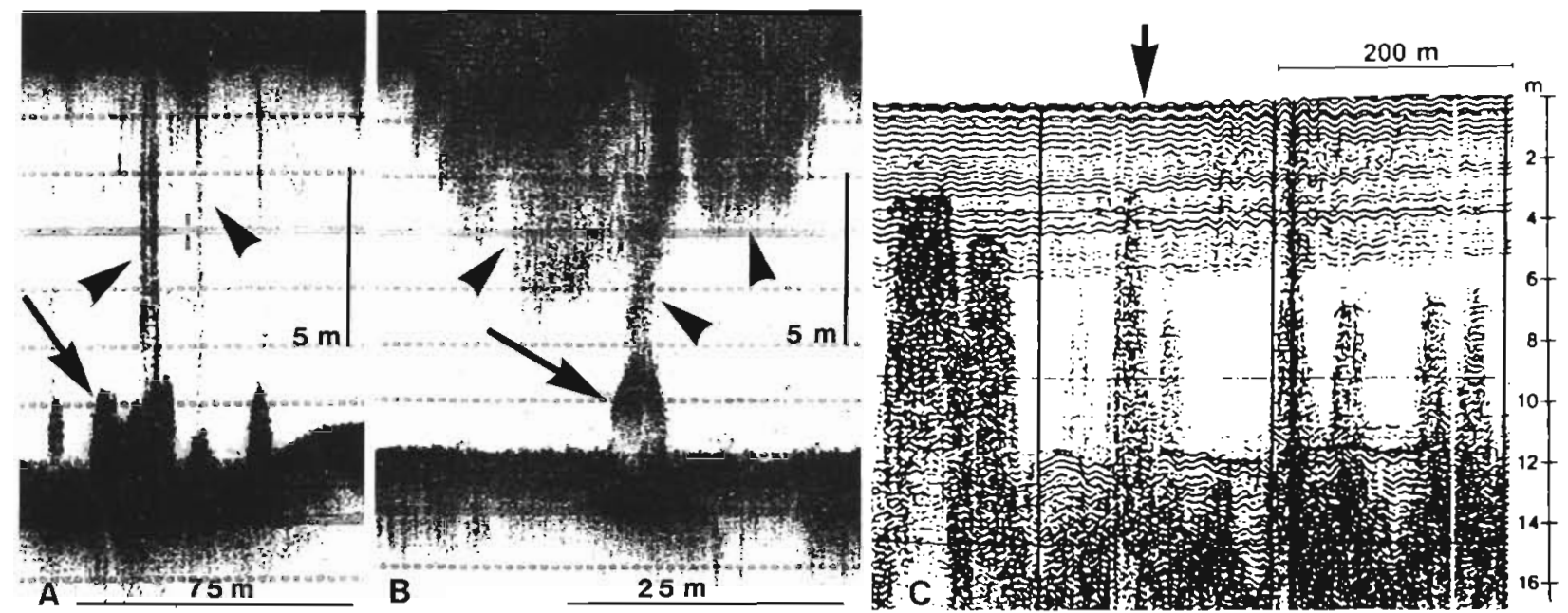

Fig. 4. (A, B) Echo-sounding transect across 'bubbling reefs' NW of Hirsholm islands. Arrows: sandstone formations on sea floor; arrowheads: gas plumes in watercolumn. (C) Seismic profile $(3.5 \mathrm{kHz})$ from seepage area SE of Frederikshavn showing plumes of gas in uppermost $10 \mathrm{~m}$ of Holocene sediment from underlying marine Late Glacial sediments. Vertical arrow: sea floor

concluded that the bacterial methane was most likely formed in the Eemian and early Weichselian marine deposits. Shallow hydrocarbon gas is known in Vendsyssel from a large number of 100 to $200 \mathrm{~m}$ deep gas wells, water wells and gas seeps from the soil (Fig. 2). The stable isotope composition of the methane from seeps NW of Hirsholm islands and north of Læsø indicates that the methane probably derives from Late Pleistocene accumulations of free gas similar to those exploited on land (Laier et al. 1992). Recent radiocarbon dating of methane from these sites (T. Laier) yielded an age of more than 40000 yr B.P., which supports the above assumption.

Stable carbon isotope analyses of the carbonate cement at the site NW of Hirsholm islands show that the carbonate probably resulted from oxidation of methane ( $N$. O. Jørgensen 1989). The stable oxygen isotopic signatures $\left(\delta^{18} \mathrm{O}\right)$ of carbonate cements range from +0.4 to $+4.85 \%$, which indicates that carbonate precipitation took place under normal marine conditions. The carbonate cement consists of high-Mg calcite, dolomite, and aragonite. High-Mg calcite appears as an intergranular cement with interlocking rhombohedra approximately 10 to $20 \mu \mathrm{m}$ across. The magnesium content of the high-Mg calcite varies markedly. Atomic absorption spectrophotometry analyses of bulk samples show magnesium concentration in the range 2.6 to $39.8 \mathrm{~mol}_{\%} \mathrm{MgCO}_{3}$. Electron microprobe analyses of individual crystals reveal concentrations as high as $42.6 \mathrm{~mol} \% \mathrm{MgCO}_{3}$. The dolomite is calciumrich with a mean stoichiometric composition of $\left(\mathrm{Ca}_{53}\right.$, $\left.\mathrm{Mg}_{47}\right) \mathrm{CO}_{3}$. The fabric of the dolomite cement is identical to that of the high-Mg calcite cement. Aragonite appears as individual needles or clusters of needles, botryoidal aragonite and, occasionally, shows dense palisade fabric on the surface of skeletal matter. High$\mathrm{Mg}$ calcite is the most widespread carbonate solid phase found and is, together with aragonite, primarily associated with lithified horizontal pavements and individual slabs, but is also observed as a part of the cement in vertical sandstone pillars (N. O. Jørgensen $1976,1979)$.

\section{Pore water chemistry and biota}

Methane saturation concentration at ambient salinity, temperature, and pressure is within the range 2.8 to $4.0 \mathrm{mM}$. Dissolved methane concentrations in the interstitial water of sediments collected $1 \mathrm{~m}$ or more from seeps NW of Hirsholm islands were generally less than 1 to $2 \mu \mathrm{M}$ in the upper $10 \mathrm{~cm}$ of sediment. Maximum aerobic methane oxidation rates were normally found either in the $0-2 \mathrm{~cm}$ or in the $2-4 \mathrm{~cm}$ hori-

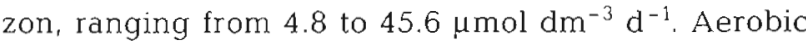
methane oxidation generally decreased with depth, occurring down to 4 or $6 \mathrm{~cm}$ depth in the muddy sediments NW of Hirsholm and down to $13 \mathrm{~cm}$ in sandy, well-flushed sediments north of Læsø. There was no close correlation between in situ methane concentration and oxidation rates, probably due to variation in gas output, mixing induced by strong currents and difficulties in sampling directly at the seeps.

Ammonia concentrations in the interstitial water varied from between 70 and $250 \mu \mathrm{M}$ in the upper $1 \mathrm{~cm}$ of sediment to $600 \mu \mathrm{M}$ at $20 \mathrm{~cm}$ depth (Fig. 5A). Peak sulphate reduction rates were between 90 and $460 \mu \mathrm{mol} \mathrm{SO}{ }_{4}^{2-} \mathrm{dm}^{-3} \mathrm{~d}^{-1}$ with maxima between 1 and 

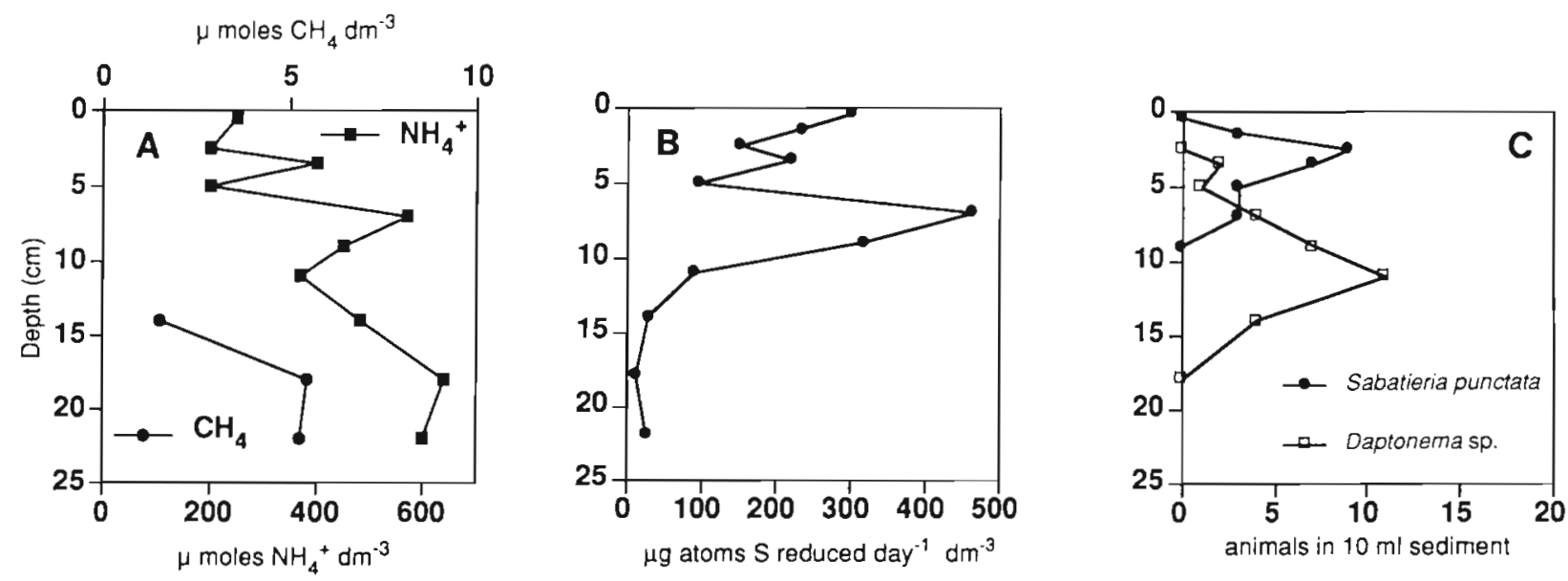

Fig. 5. Depth profiles of (A) ammonia and methane, (B) sulphate reduction rates, and (C) abundances of 2 nematode species in a sediment core taken $1.5 \mathrm{~m}$ from an active seep, NW of Hirsholm islands

$8 \mathrm{~cm}$ sediment depth (Fig. 5B). Integrated values for the upper $10 \mathrm{~cm}$ of the sediment column gave rates between 4.2 and $26.6 \mathrm{mmol} \mathrm{SO}_{4}{ }^{2-} \mathrm{m}^{-2} \mathrm{~d}^{-1}$. These rates are up to 7 times higher than those recorded elsewhoro in the Kattegat from muddy sediment and similar water depths, but unaffected by methane seepages (B. B. Jørgensen 1989, Thode-Andersen \& Jørgensen 1989 , B. B. Jørgensen et al. 1990). It is probable that there is a higher organic input into the sediment in the vicinity of the seepages, due to the dense macrophyte production on the sandstone formations, resulting in a high sulphate reduction rate in the sediment. Only 1 core with high dissolved methane concentrations, 90 to $400 \mu \mathrm{M}$, was obtained from a small seepage NW of Hirsholm islands. This core showed significantly lower ammonia concentrations, 37 to $206 \mu \mathrm{M}$, and sulphate reduction rates, 50 to $190 \mu \mathrm{mol} \mathrm{SO}{ }_{4}^{2-} \mathrm{dm}^{-3} \mathrm{~d}^{-1}$, compared to a core taken $0.5 \mathrm{~m}$ away in which the maximum methane concentrations were only $15 \mu \mathrm{M}$ at $20 \mathrm{~cm}$ depth with ammonia concentrations of 200 to $400 \mu \mathrm{M}$ and sulphate reduction rates varying between 153 and $300 \mu \mathrm{mol} \mathrm{SO}_{4}{ }^{2-} \mathrm{dm}^{-3} \mathrm{~d}^{-1}$. Elemental sulphur, acid-volatile sulphide and chromous-reducible sulphur were also lower in the seep core, despite a strong hydrogen sulphide odour, with a mean concentration of $68 \mathrm{mg}$-at. reduced sulphur $\mathrm{dm}^{-3}$ for the seep compared to $107 \mathrm{mg}$-at. reduced sulphur $\mathrm{dm}^{-3}$ for the control core. This is believed to be due to winnowing of the sediment by the escaping gas and by flushing of the surface sediments close to the seeps by the water flow generated by the gas bubble stream. An equivalent volume of water is drawn into the sediment to replace that displaced by the gas. This stimulates oxidative processes in the immediate vicinity of the gas outlets. The hydrogen sulphide appears to be carried from deeper horizons in the gas stream. Hydrogen sulphide is a common component of the gas as indicated by the smell of escaping gas at the intertidal site, the odour of sediment collected directly over the seeps and the prosence of Beggiatoa mats on sundstones in direct contact with the gas.

The metazoan fauna is concentrated in the topmost $2 \mathrm{~cm}$ of the muddy sediment around the sandstone formations NW of Hirsholm islands. No biogenic structures, tubes or burrows, are visible below 2 to $5 \mathrm{~cm}$ depth. The fauna consists mainly of organisms that pass through a $500 \mu \mathrm{m}$ mesh size sieve but are retained on a sieve with a $45 \mu \mathrm{m}$ mesh size. We found 38 species of nematodes, oligochaetes and polychaetes, with an overall abundance of $650 \times 10^{3}$ ind. $\mathrm{m}^{-2}$ and a biomass of less than $2 \mathrm{~g} \mathrm{C} \mathrm{m}^{-2}$. These figures are low compared to results obtained from a control area north of Hirsholm islands at Jerup Strand (similar sample size, water depth and sediment grain size) harbouring a diverse and abundant macrofauna, dominated by the polychaetes Scoloplos armiger and Polydora caeca and the bivalve Venus gallina, comprising ca $62 \mathrm{~g} \mathrm{C} \mathrm{m}^{-2}$ (Nordjyllands amt 1991). We ascribe the lower diversity and biomass of the infauna at the seep site to continual stress of elevated toxic hydrogen sulphide concentrations (cf. Vismann 1991). Two nematodes, Sabatieria punctata and a new Daptonema species, penetrate deepest into the sediment and are most abundant in sediment horizons above and below the sulphate reduction peak, respectively (Fig. 5C), $S$. punctata is known to have its population maximum at the redox potential discontinuity layer (Jensen 1983). How Daptonema sp. is adapted to hydrogen sulphide and whether it has an anaerobic metabolism or is an extreme micro-aerophilic organism is now being studied. Preliminary results indicate that Daptonema sp. is physiologically related to Paramonohystera 
wieseri, a free-living marine nematode being adapted to anaerobic conditions (Wieser et al. 1974). The interstitial fauna in the sandy sediment around the sandstone formations north of Læesø occur down to at least $22 \mathrm{~cm}$ depth (maximum depth of coring). Here the nematode species Leptonemella aphanothecae is one of the deepest penetrating metazoans. It harbours symbiotic bacteria on the cuticle along the whole body. The bacteria are sulphur-oxidizers detoxifying hydrogen sulphide as is also known in related species (Powell et al. 1979, Schiemer et al. 1990). Moreover, TEM observations show that $L$, aphanothecae feeds on the attached sulphur bacteria and digest them in the posterior part of the gut. It appears that most of the food is derived from eating the ectosymbionts.

\section{Biota on the 'bubbling reefs'}

Over 100 macrobenthic animal species have been found on the 'bubbling reefs' (Appendix). These include the polychaete Polycirrus norwegicus and the bivalve Kellia suborbicularis which are rare elsewhere in Danish waters. Nowhere else in Danish waters have we observed so many Cancer pagurus and Homarus vulgaris. The landscapes provide shelter for fish fry, and caves close to the sea floor provide places for Gadus morhua and Pollachius virens. The most conspicous invertebrates are the anthozoans Metridium senile, Alcyonium digitatum and Tealia felina (cf. Fig. 1). $M$. senile may cover the entire uppermost half of the tall pillars and outermost edges of the slabs. Colonies of $A$. digitatum are patchily located in more protected areas whereas large numbers of $T$. felina are found at the feet of the sandstone formations. The outermost 1 to $2 \mathrm{~cm}$ of the loosely cemented sandstone may have numerous, closely-spaced narrow borings which are caused by the boring sponge Cliona celata (Fig. 6A, B) and the polychaete Dodocaceria concharum, and slightly larger and deeper burrows are possibly made by the bivalve Hiatella sp. (Fig. 6 C, D). These borings expand the residential surface for other organisms and the empty burrows are inhabited by small animals including nematodes, polychaetes, bivalves and echinoderms. The macrophyte vegetation is mostly at the top of the tallest formations, and is dominated by Corallina officinalis, Laminaria spp. and different Bangiophyceae; Lithothamnion sp. is present almost everywhere. The 'bubbling reefs' with their rich fauna and flora are indeed oases on the sea floor.

The fauna on the sandstone formations at the 2 sites at the Hirsholm islands were analyzed for stable carbon isotope ratios to determine the extent to which the fauna depends on a food chain based on methaneoxidizing (methanotrophic) or sulphur-oxidizing (thio-
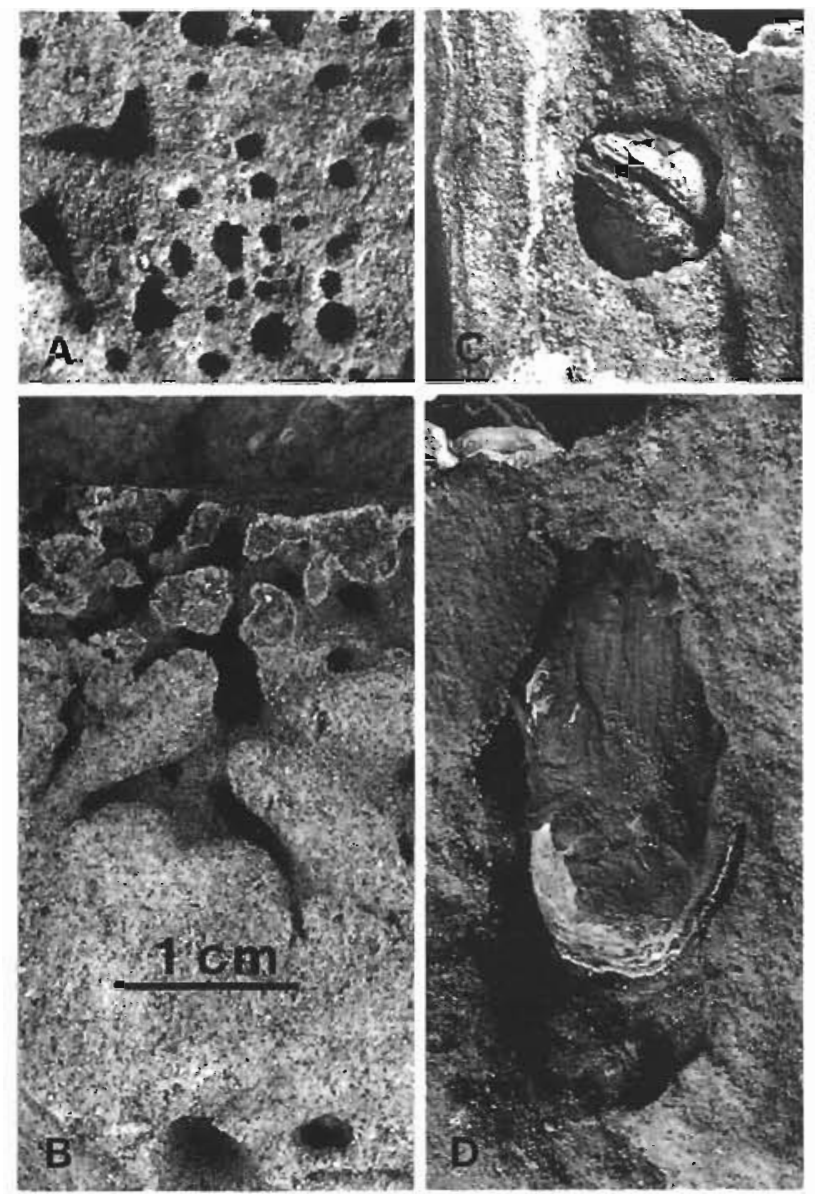

Fig. 6. Borings in outermost carbonate-cemented sandstone. (A, B) Dense and narrow borings made by the boring sponge Cliona celata in surface and cross section views, respectively. (C, D) Boring made by the bivalve Hiatella sp. in surface and cross-section views, respectively, with the bivalve in the burrow. All to same scale

trophic) bacteria. Control animals were collected from a locality at a stony reef $200 \mathrm{~m}$ east of the seepage NW of the Hirsholm islands. The results are shown in Table 1. The sandstone samples from the SE site were almost covered by Metridium senile of which 21 specimens were analyzed and had a mean $\delta^{13} \mathrm{C}$ of $-19 \%$ $\pm 0.9 \mathrm{SD}$. It has not been possible to find a control site in the region where this animal could be collected. Animals from the seep sites had, except the bryozoan Plagioecia patina, $\delta^{13} \mathrm{C}$ values within the range of animals in a phytoplankton-based food web (Fry \& Sherr 1984). The species from the seepage NW of the Hirsholm islands were on average $1.2 \%$ more ${ }^{13} \mathrm{C}$ depleted than those from the control site. Most of this difference was due to the less abundant bryozoan $P$. patina which was growing close to a Beggiatoa-like bacterial mat. The greater ${ }^{13} \mathrm{C}$-depletion observed in the bryozoan could be due to carbon input from 
Table 1. Carbon isotope ratios $\left(\delta^{13} \mathrm{C}, \%\right)$ for animals from 2 seep sites and from a control site

\begin{tabular}{|c|c|c|c|}
\hline \multirow[t]{2}{*}{ Species } & \multicolumn{2}{|c|}{ Seep sites } & \multirow{2}{*}{$\begin{array}{c}\text { Control site } \\
\text { NW of Hirsholm } \\
\text { islands }\end{array}$} \\
\hline & $\begin{array}{l}\text { NW of Hirsholm } \\
\text { islands }\end{array}$ & $\begin{array}{l}\text { SE of Hirsholm } \\
\text { islands }\end{array}$ & \\
\hline Heteronomia squamula & $-19.5,-21.5$ & & $-18.8,-20.8$ \\
\hline Nudibranch spp. & -20.3 & $-18.8,-19.9$ & -21.3 \\
\hline Balanus balanus & -19.2 & $\begin{array}{c}-18.7 \quad n=5 \\
(-18.4 \text { to }-19.4\}\end{array}$ & -18.4 \\
\hline Eupagurus bernhardus & -18.3 & -17.7 & -18.4 \\
\hline Ophiotrix fragilis & $-18.2,-19.3$ & $-18.6,-19.4$ & -17.6 \\
\hline Asterias rubens & $-18.0,-18.7$ & $\begin{array}{c}-18.1 \quad n=7 \\
(-17.0 \text { to }-18.9)\end{array}$ & $\begin{array}{c}-17.2 \quad n=4 \\
(-15.9 \text { to }-18.0)\end{array}$ \\
\hline Plagioecia patina & -23.9 & & -18.9 \\
\hline
\end{tabular}
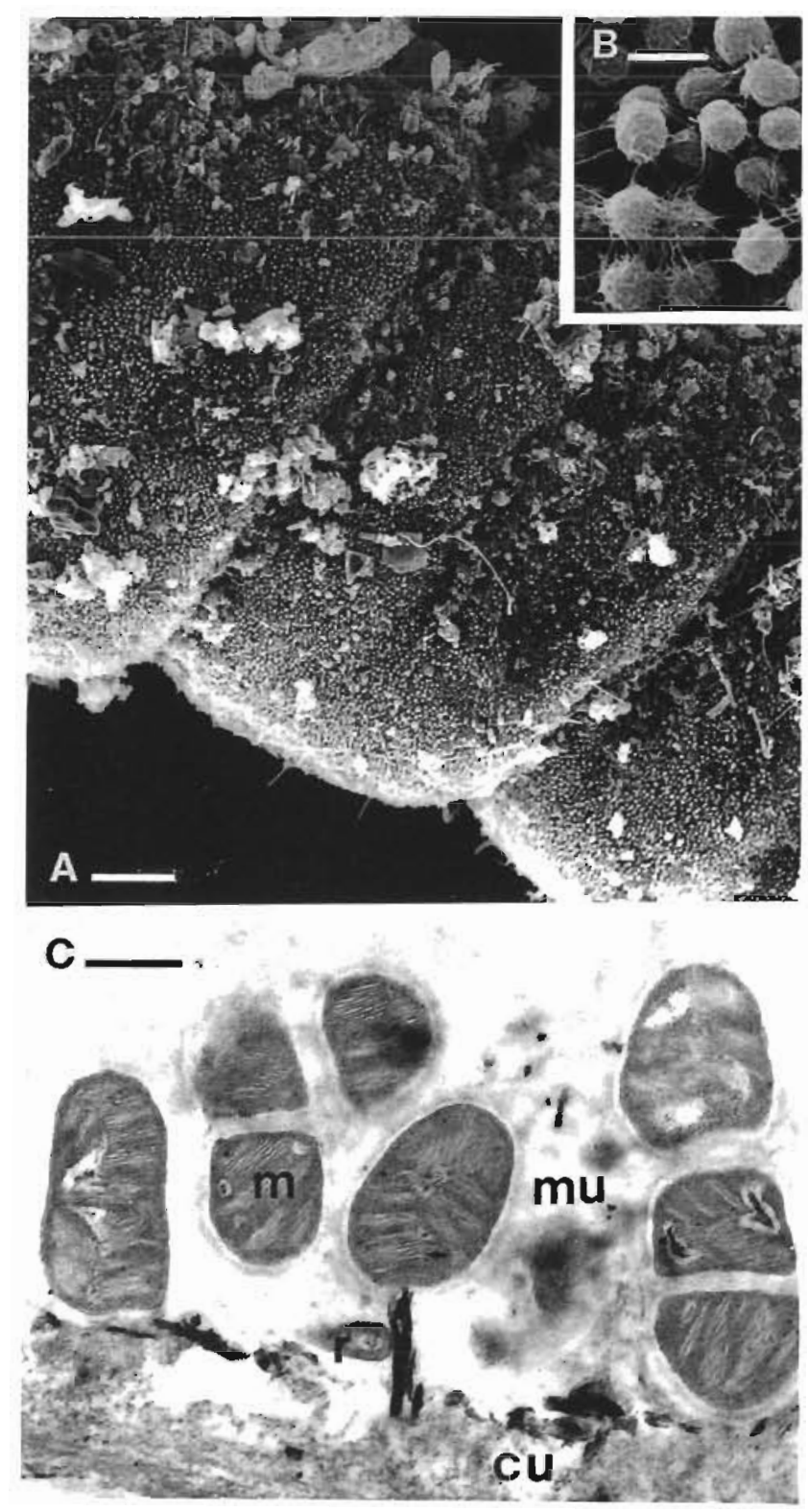

the mats of presumed sulphur-oxidizing bacteria. A sample of bacteria, which had been exposed to gas bubbles and contained Beggiatoa-like bacteria as well as other filamentous forms, was scraped from a sandstone and found to have a $\delta^{13} \mathrm{C}$ of $-43.4 \%$. Since both ine cabou dioxide $(-19$ io $-27 \%)$ and the methane $(-63.5 \%)$ in the gas are very ${ }^{13} \mathrm{C}$-depleted, the light carbon isotope ratios for the bacterial mat could reflect either fixation of ${ }^{13} \mathrm{C}$-depleted $\mathrm{CO}_{2}$ by sulphur oxidizing chemoautotrophs, or assimilation of ${ }^{13} \mathrm{C}$-depleted methane by methanotrophs. In conclusion, the fauna inhabiting the 'bubbling reefs' in the Kattegat are largely dependent upon a plankton-based food chain. This observation is similar to that described for the fauna around a methane seep in a North Sea pockmark (Dando et al. 1991).

Sandstone samples overgrown with mixed populations of bryozoa, hydroids and sponges were collected at sites NW of the Hirsholm islands which were exposed to a stream of gas bubbles and at a control locality $15 \mathrm{~m}$ away from seepages, to measure bacterial methane oxidation. During incubation with $1 \mu \mathrm{M}$ methane the seep samples showed very active methane consumption rates of 1.1 to $3.0 \mathrm{nmol}$ $\mathrm{cm}^{-2} \mathrm{~h}^{-1}$ compared to 0.01 to $0.1 \mathrm{nmol} \mathrm{cm}^{-2} \mathrm{~h}^{-1}$ for

Fig. 7 Epibiotic bacterla on the stalk of the hydroid Eudendrium arbuscula from a rock surfice close to a methane outlet. (A) SEM view showing nearly complete colonization of the surface with one dominant type of bacteria. (B) Highes magnification showing rod-like bacteria connected by mucilage. (C) TEM view of an ultrathin section through the bacterial layer. Rod-like bacteria with extensive internal membrane stacks (m) are arranged vertically to the cuticle (cu) of the hydroid, sometimes forming short cell chains. They are embedded in mucilage-like material (mu), occasionally containing smaller bacterial. rods (r). Scale bars: (A) $20 \mu \mathrm{m}$; (B) $1 \mu \mathrm{m}$; (C) $0.5 \mu \mathrm{m}$. Photo: Rolf Schmaljohann 
the control samples. Recent investigations at hydrothermal vents of surfaces of invertebrates, i.e. skins, shells and tubes, gave comparable results in the range 0.42 to $24 \mathrm{nmol} \mathrm{CH}_{4} \mathrm{~cm}^{-2} \mathrm{~h}^{-1}$ at identical methane concentrations (de Angelis et al. 1991). No aerobic methane oxidation could be detected in water samples taken $0.5 \mathrm{~m}$ above the seepage, probably because of mixing induced by strong water currents in this area. SEM observations (Fig. 7A, B) of surfaces exposed to gas bubbles show a dense biofilm composed of a variety of rod-like, budding and filamentous bacteria. Several types of methanotrophic bacteria were isolated and are being studied. Prominent parts of attached animals like the spines of bryozoa or stalks and thecae of hydroids were also densely colonized by bacteria. Some of these microbial populations are similar to microbial mats found at surfaces of invertebrates close to deep-sea hydrothermal vents (Jannasch \& Wirsen 1981, de Angelis et al. 1991). TEM observations revealed that the dominant bacteria colonizing the stalk of the hydroid Eudendrium arbuscula contain membrane stacks typical of Type I methanotrophic bacteria (Fig. 7).

Acknowledgements. We acknowledge the facilities at the Havbiologisk Feltlaboratorium, University of Copenhagen, Frederikshavn. Dr Heye Rumohr, Tommy Hansen, Knud Erik Horby, Frederikshavn SCUBA Diving Club, local fishermen in Frederikshavn and Læsø, the environmental office of Nordjyllands Amt, the Danish navy at Fredrikshavn and the crew of RV 'Litorina' are thanked for their enthusiastic support of the study. We thank Drs Claus Nielsen, Kurt W. Ockelmann, Kay W. Petersen, Mary Petersen and Ole Tendal for identification of some animals, Karen Bigley and Javier Alcala-Herrera for the stable carbon isotopic analysis and Holger Knudsen for the close-up photographs of sandstones. Dr Martin Hovland provided fruitful comments on the manuscript. Financial assistance was provided by the Texas A\&M University Sea Grant College Program to R.A.B.; the Institute of Petroleum, the British Council and the CEC MAST programme contract No. 0044 to P.R.D.; the German Research Council to R.S.; and the Carlsberg Foundation to Dr Tom Fenchel and P.J.

Appendix. Macrofauna on 'bubbling reefs' in the Kattegat. "Common species

\begin{tabular}{|c|c|c|}
\hline $\begin{array}{l}\text { PORIFERA } \\
\text { - Cliona celata }\end{array}$ & $\begin{array}{l}\text { Caulleriella aff. killariensis } \\
\text { Lagisca externuata }\end{array}$ & $\begin{array}{l}\text { PANTOPODA } \\
\text { Pallene brevirostris }\end{array}$ \\
\hline \multirow{4}{*}{$\begin{array}{l}\text { HYDROZOA } \\
\text { Eudendrium arbuscula } \\
\text { Hydractinia echinata } \\
\text { Ectopleura larynx }\end{array}$} & Polydora ciliata & CIRRIPEDIA \\
\hline & Polydora coeca & - Verruca stroemia \\
\hline & Polycirrus norwegicus & Balanus balanus \\
\hline & OLIGOCHAETA & DECAPODA \\
\hline \multirow{4}{*}{$\begin{array}{l}\text { ANTHOZOA } \\
\text { - Metridium senile } \\
\text { - Tealia felina } \\
\text { - Alcyonium digitatum }\end{array}$} & $4 \mathrm{spp}$ & Eupagurus bernhardus \\
\hline & GASTROPODA (- Nudibranchia) & - Porcellana longicornis \\
\hline & Acmaea virginea & - Cancer pagurus \\
\hline & Gibbula cineraria & Stenorhynchus rostratus \\
\hline \multirow{5}{*}{$\begin{array}{l}\text { NEMERTEA } \\
\text { - Emplectonema gracile } \\
\text { Micrura fasciolata } \\
\text { Lineus bilineatus } \\
\text { Prostomatella obscura }\end{array}$} & - Cingula striata & ISOPODA \\
\hline & Crepidula fornicata & Jamira maculosa \\
\hline & - Alvania punctura & Munna minuta \\
\hline & $\begin{array}{l}\text { Rissoa albella } \\
\text { - Rissoa parva }\end{array}$ & AMPHIPODA \\
\hline & $\begin{array}{l}\text { Rissoa membranacea } \\
\text { Risoa }\end{array}$ & $\begin{array}{l}\text { - Phtisica marina } \\
\text { - Corophium bonelli }\end{array}$ \\
\hline \multirow{6}{*}{$\begin{array}{l}\text { POLYCHAETA } \\
\text { Lepidonotus squamatus } \\
\text { Harmothoe fragilis } \\
\text { Harmothoe aff. elisabethae } \\
\text { Scalisetosus sp. } \\
\text { Pholoe inornata } \\
\text { Eulalia viridis }\end{array}$} & Hinia pygmaeus & Cressa dubia \\
\hline & - Chrysallida spiralis & Microdeutopus propinquus \\
\hline & $\begin{array}{l}\text { - Odostomia plicate } \\
\text { Odostomia eulimoides }\end{array}$ & 2 spp. \\
\hline & Retusa truncatula & SIPUNCULIDA \\
\hline & Philine denticulata & Golfingia minuta \\
\hline & NUDIBRANCHIA & BRYOZOA \\
\hline $\begin{array}{l}\text { Nereimyra punctata } \\
\text { Typosyllis armillaris }\end{array}$ & - Goniodoris nodosa & Conopeum seurati \\
\hline Exogone hebes & Acanthodoris pilosa & - Crisia eburnea \\
\hline Proceraea cornuta & Onchidoris muricata & Scrupocellaria scruposa \\
\hline Nereis pelagica & Archidoris pseudoargus & $\begin{array}{l}\text { Alcyonianum nissutum } \\
\text { Electra pilosa }\end{array}$ \\
\hline Sphaerodorum flavum & $\begin{array}{l}\text { Coryphella verrucosa } \\
\text { Cuthona foliata }\end{array}$ & Membranipora membranacea \\
\hline Pherusa plumosa & $\begin{array}{l}\text { Cuthona follata } \\
\text { Doto coronata }\end{array}$ & Escharella immersa \\
\hline $\begin{array}{l}\text { Arenicola marina } \\
\text { - Pomatoceros triqueter }\end{array}$ & Jorunna tomentosa & Plagioecia patina \\
\hline Hydroides norwegica & BIVALVIA & ECHINODERMATA \\
\hline Sabellaria spinulosa & Mytilus edulis & Ophiopholis aculeata \\
\hline Heteromastus filiformis & Modiolarca tumida & 'Ophiotrix fragilis \\
\hline Autolytus prolifer & Monia patelliformis & Asterias rubens \\
\hline Nicolea zostericola & - Heteronomia squamula & Martasterias glacialis \\
\hline Spirorbis spirillum & - Hiatella sp. & ASCIDIA \\
\hline - Dodocaceria concharum & Parvicardium ovale & - Botrylloides leachii \\
\hline Cirratulus incertus & Mysella bidentata & Botryllus schlosseri \\
\hline Caulleriella aff. fragilis & Kellia suborbicularis & Styela coriacea \\
\hline
\end{tabular}




\section{LITERATURE CITED}

Brey, T., Rumohr, H., Ankar, S. (1988). The energy content of macrobenthic invertebrates: general conversion factors from weight to energy. J. exp. Mar. Biol. Ecol. 117: $271-278$

Dando, P. R., Austen, M. C., Burke, R. A. Jr, Kendall, M. A., Kennicutt, M. C. II, Judd, A. G., Moore, D. C., O'Hara, S. C. M., Schmaljohann, R., Southward, A. J. (1991). Ecology of a North Sea pockmark with an active methane seep. Mar. Ecol. Prog. Ser. 70: 49-63

de Angelis, M. A., Reysenbach, A.-L., Baross, J. A. (1991). Surfaces of hydrothermal vent invertebrates: Sites of elevated microbial $\mathrm{CH}_{4}$ oxidation activity. Limnol. Oceanogr. 36: $570-577$

EUGENO-S Working group (1988). Crustal structure and tectonic evolution of the transition between the Baltic Shield and the northern German Caledonides. In: Freeman, R., Bertelsen, A., Müller, St. (eds.) The European Geotraverse, Part 4. Tectonophysics 150: 253-348

Fry, B., Sherr, E. B. (1984) $\delta \delta^{13} \mathrm{C}$ measurements as indicators of carbon flow in marine and freshwater ecosystems. Contr. mar. Sci. $27: 13-47$

Hovland, M. (1990). Do carbonate reefs form due to fluid seepage? Terra Nova 2: $8-18$

Hovland, M., Judd, A. (1988). Seabed pockmarks and seepages. Graham and Trotman Ltd, London

Jannasch, H. W., Wirsen, C. (1981). Morphological survey of microbial mats near deep-sea thermal vents. Appl. environ. Microbiol. 41:528-538

Jensen, P. (1983). Meiofaunal abundance and vertical zonation in a sublittoral soft bottom, with a test of the Haps corer, Mar. Biol. 74: 319-326

Jørgensen, B. B. (1989). Sulfate reduction in marine sediments from the Baltic Sea - North Sea transition. Ophelia 31: $1-15$

Jørgensen, B. B., Bang, M. Blackburn, T. H. (1990). Anaerobic mineralization in marine sediments from the Baltic Sea - North Sea transition. Mar. Ecol. Prog. Ser. 59: 39-54

Jorgensen, N. O. (1976). Recent high magnesian calcite/ aragonite cementation of beach and submarine sediments from Denmark. J. sedim. Petrol. 46: 940-952

Jørgensen, N. O. (1989). Holocene methane-derived dolomite-cemented sandstone pillars from the Kattegat, Denmark. Mar. Geol. 88: 71-81

Jørgensen, N. O. (1992). Methane-derived carbonate cementation of marine sediments from the Kattegat, Denmark:

This article was submitted to the editor geochemical and geological evidence. Mar. Geol. 103: $1-13$

Jørgensen, N. O., Laier, T., Buchardt, B., Cederberg, T. (1990). Shallow hydrocarbon gas in the northern Jutland-Kattegat region, Denmark. Bull. geol. Soc., Denmark 38: 69-76

Kulm, L. D., Suess, E., Moore, J. C., Carson, B., Lewis, B. T., Ritger, S. D., Kadko, D. C., Thornsburg, T. M., Embley, R. W., Rugh, W. D., Massoth, G. J., Langseth, M. G., Cochrane, G. R., Scamman, R. I. (1986). Oregon Subduction zone: venting, fauna, and carbonates. Science 231: $561-566$

Laier, T., Jørgensen, N. O., Buchardt, B., Cederberg, T. (1992). Accumulation and seepages of biogenic gas in northern Denmark. Cont. Shelf. Res. (in press)

Nordjyllands amt (1991). Bundfaunamonitering Kattegat april 1990 udført af Marin ID. Kobenhavn. Nordjyllands Amt, Aalborg, p. 1-29

Powell, E. N., Crenshaw, M. A., Rieger, R. M. (1979). Adaptation to sulfide in the meiofauna of the sulfide system. I. ${ }^{35} \mathrm{~S}$-sulfide accumulation and the presence of a sulfide detoxification system. J. exp. mar. Biol. Ecol. 37: 57-76

Ritger, S., Carson, B., Suess, E. (1987). Methane-derived authigenic carbonates formed by subduction-induced porewater expulsion along the Oregon/Washington margin. Geol. Soc. Am. Bull. 98: 147-156

Roberts, H. H., Sassen, R., Aharon, P. (1988). Petroleumderived authigenic carbonates on the Louisiana continental slope. In: Ocean '88 Praceedings 1. Institute of Electrical and Electronics Engineers, New York, p. 101-105

Schiemer, F, Novak, R., Ott, J. (1990). Metabolic studies on thiobiotic free-living nematodes and their symbiotic microorganisms. Mar. Biol. 106: 129-137

Suess, E., Whiticar, M. J. (1989). Methane-derived $\mathrm{CO}_{2}$ in pore fluid expelled from the Oregon Subduction zone. Palaeogr. Palaeoclimatol. Palaeoecol. 71: 119-136

Thode-Andersen, S., Jørgensen, B. B. (1989). Sulfatereduction and the formation of ${ }^{35} \mathrm{~S}$-labeled $\mathrm{FeS}, \mathrm{FeS}_{2}$, and $\mathrm{S}^{\circ}$ in coastal marine sediments. Limnol. Oceanogr. 34: $793-806$

Vismann, B. (1991). Sulfide tolerance: physiological mechanisms and ecological implications. Ophelia 34:1-27

Whiticar, M. J., Faber, E. (1986). Methane oxidation in sediment and water column environments. Org. Geochem. 10: $759-768$

Wieser, W., Ott, J., Schiemer, F., Gnaiger, E. (1974). An ecophysiological study of some meiofauna species inhabiting a sandy beach at Bermuda. Mar. Biol. 26: 235-248

Manuscript first received: January 30, 1992

Revised version accepted: April 30, 1992 